Meta

Journal des traducteurs

Translators' Journal

\title{
Public Service Interpreting and Translation: Moving Towards a (Virtual) Community of Practice
}

\section{Danielle D’Hayer}

Volume 57, numéro 1, mars 2012

La CIUTI, chef de file pour la promotion de l'employabilité et de la recherche

CIUTI: Leader in Advocating Employability and Research

URI : https://id.erudit.org/iderudit/1012751ar

DOI : https://doi.org/10.7202/1012751ar

Aller au sommaire du numéro

Éditeur(s)

Les Presses de l’Université de Montréal

ISSN

0026-0452 (imprimé)

1492-1421 (numérique)

Découvrir la revue

Citer cet article

D'Hayer, D. (2012). Public Service Interpreting and Translation: Moving Towards a (Virtual) Community of Practice. Meta, 57(1), 235-247.

https://doi.org/10.7202/1012751ar
Résumé de l'article

Après de longues batailles, la traduction et l'interprétation communautaires accèdent enfin au stade de la professionnalisation. Quel que soit le pays où ces activités s'exercent, les mêmes questions se posent : définir la profession, répondre aux besoins des langues minoritaires ou rares, informer les diverses parties impliquées, formaliser la formation, sans oublier les normes de qualité. Actuellement, le financement de la formation des interprètes et traducteurs communautaires n'est pas subventionné, ce qui amène les parties impliquées à travailler différemment. Le modèle des communautés de pratique est un modèle qui encourage le partage des ressources et l'échange des connaissances, au-delà des limites imposées par les programmes de formation, les écoles ou les contextes nationaux. Les nouvelles technologies, telles que les conférences virtuelles et les espaces de stockage partagés constituent le principal « chaînon manquant » de la progression de la formation. Les acteurs du domaine doivent se regrouper et unifier leurs efforts pour favoriser des échanges constructifs et novateurs qui amélioreraient leur profession. Certaines spécialisations de la traduction et de l'interprétation communautaires telles que la traduction et l'interprétation juridiques ont su faire tomber de nombreuses barrières et obtenir la reconnaissance professionnelle recherchée. Toutefois, les professions de traducteur et d'interprète communautaires doivent inclure tous les contextes possibles, notamment le contexte médical ainsi que les administrations publiques. Lorsque la profession sera complètement définie, il sera alors possible de la rassembler avec l'interprétation de conférence pour les langues parlées et pour la langue des signes sous la seule houlette de l'interprétation. C'est ce que les communautés de pratique permettent de réaliser, quels que soient leur ampleur, leur identité linguistique, et leur mode de fonctionnement, présentiel ou virtuel.
Ce document est protégé par la loi sur le droit d'auteur. L'utilisation des services d’Érudit (y compris la reproduction) est assujettie à sa politique d'utilisation que vous pouvez consulter en ligne.

https://apropos.erudit.org/fr/usagers/politique-dutilisation/ 


\title{
Public Service Interpreting and Translation: Moving Towards a (Virtual) Community of Practice
}

\author{
DANIELLE D'HAYER \\ London Metropolitan University, London, UK \\ d.dhayer@londonmet.ac.uk
}

\section{RÉSUMÉ}

Après de longues batailles, la traduction et l'interprétation communautaires accèdent enfin au stade de la professionnalisation. Quel que soit le pays où ces activités s'exercent, les mêmes questions se posent: définir la profession, répondre aux besoins des langues minoritaires ou rares, informer les diverses parties impliquées, formaliser la formation, sans oublier les normes de qualité. Actuellement, le financement de la formation des interprètes et traducteurs communautaires n'est pas subventionné, ce qui amène les parties impliquées à travailler différemment. Le modèle des communautés de pratique est un modèle qui encourage le partage des ressources et l'échange des connaissances, au-delà des limites imposées par les programmes de formation, les écoles ou les contextes nationaux. Les nouvelles technologies, telles que les conférences virtuelles et les espaces de stockage partagés constituent le principal «chaînon manquant» de la progression de la formation. Les acteurs du domaine doivent se regrouper et unifier leurs efforts pour favoriser des échanges constructifs et novateurs qui amélioreraient leur profession. Certaines spécialisations de la traduction et de l'interprétation communautaires telles que la traduction et l'interprétation juridiques ont su faire tomber de nombreuses barrières et obtenir la reconnaissance professionnelle recherchée. Toutefois, les professions de traducteur et d'interprète communautaires doivent inclure tous les contextes possibles, notamment le contexte médical ainsi que les administrations publiques. Lorsque la profession sera complètement définie, il sera alors possible de la rassembler avec l'interprétation de conférence pour les langues parlées et pour la langue des signes sous la seule houlette de l'interprétation. C'est ce que les communautés de pratique permettent de réaliser, quels que soient leur ampleur, leur identité linguistique, et leur mode de fonctionnement, présentiel ou virtuel.

\begin{abstract}
Following many battles, Public Service Interpreting and Translation (PSIT) is gradually evolving towards professionalisation. Wherever it is practiced, common issues have been identified: defining the profession, providing interpreting services for rare or minority languages, educating stakeholders, moving from training to education, and last but not least interpreting and translation quality. The lack of funding for PSIT courses within the current financial context is forcing stakeholders to work differently. The community of practice model can help PSIT stakeholders share resources and knowledge beyond the traditional boundaries set by courses, schools or countries. New technologies such as virtual conference tools and shared repositories are the essential "missing link" towards the progress of PSIT education. PSIT stakeholders need to join forces and pool efforts towards a constructive and innovative dialogue that would enhance the profession. Some forms of PSIT, such as legal interpreting and translation, have already broken barriers and gained professional recognition. However, PSIT should include all forms of PSIT contexts, including the medical or local government. Finally, once fully defined, PSIT and conference interpreting for spoken and sign languages could finally come together under the
\end{abstract}


Interpreting profession umbrella. This is the achievable ultimate aim when working as communities of practice, small or large, language specific or generic, face to face or virtual.

\section{MOTS-CLÉS/KEYWORDS}

traduction et interprétation communautaires, communauté de pratique, enseignement à distance, apprentissage contextualisé, professionnalisation

PSIT (Public Service Interpreting and Translation), community of practice, remote teaching and learning, situated learning, professionalisation

\section{Introduction}

Interpreting is a spontaneous form of communication. For many years, members of family, friends or improvised people who happened to be at the right place at the right time would help break language barriers and help a person understand a doctor, a police officer or an immigration officer, trying their best at transferring medical or legal questions, getting information and even breaking challenging news to a person such as a medical diagnosis or a legal sentence.

Thankfully, as the world opens up and people travel, sometimes escaping war conflicts or simply looking for a better future, public service interpretation and translation services have emerged. In some countries such as Sweden, Australia, the USA and the UK, decisions have been made sometimes at a governmental level, sometimes not, raising standards for the professionalisation of PSIT. In many other countries PSIT is in its infancy or not even acknowledged.

This paper is an attempt to establish the current context of PSIT in the UK, presenting the challenges encountered by stakeholders involved in the process of PSIT. As the current financial crisis affects many institutions, financial cuts are forcing institutions to revisit their way of operating at a conceptual level. Daunting at first, it is an opportunity to operate in a new creative setting, using resources innovatively. New technologies are continuously affecting the way we communicate, access information and operate. For PSIT, this is an opportunity to think in terms of partnerships and communities of practice. This is particularly important when applied to the training of PSIT professionals. New technologies are providing exciting horizons to extend communities of practice in a virtual environment, offering minority languages the resources they deserve.

\section{Public service interpreting training: current context in the UK}

Interpreting studies traditionally concentrate on conference interpreting, hence the numerous existing postgraduate interpreting programs in the UK, Europe and the world. Most of the existing courses try to match the requirement set by AIIC (Association Internationale des Interprètes de Conférence) or the standards set by the European Master's in Conference Interpreting (EMCI). ${ }^{1}$

Over the last 20 years, a new branch of the interpreting profession defined as Public Service Interpreting (PSI) has emerged taking the interpreting profession by surprise. As a result, not only has the interpreting profession been forced to look at its status and its future but it also had to consider the professionalisation of PSI.

New technologies play an innovative role that can no longer be ignored in the world of interpreting. Remote Interpreting is a controversial topic still lacking in 
quality standards and ethics. Public services such as the police, the ambulance services use telephone interpreting services every day; video conference interpreting and web streaming facilities are also gaining popularity on the private market, in the Criminal Justice System or by the London Metropolitan Police.

Though telephone interpreting and remote interpreting are a growing trend, little thought has been given to readjusting interpreting training to the new media. London Metropolitan University has incorporated telephone interpreting and videoconference interpreting in their interpreting course design as early as 2004 . Nataly Kelly (2008) is the first author to have written a book on telephone interpreting with teaching materials and gives a thorough understanding of the concept of telephone interpreting in the public and commercial sector in the USA (Kelly 2008). Finally, the AVIDICUS project - Assessing videoconference interpreting in the Criminal Justice System (EU Criminal Justice Programme, Project JLS/2008/JPEN/03), followed by the IVY project (Interpreting in Virtual Reality - EU Lifelong Learning Program, Project 511862-2010-LLP-UK-KA-KA3MP) demonstrate that we need to anticipate, prepare, understand and assess interpreting and translation skills within a new virtual dimension.

\subsection{Public Service Interpreting (PSI), Community Interpreting, Legal Interpreting, what is the difference, what do they have in common, what do they refer to?}

As an emerging profession public service interpreting still needs to be defined.

In literature, the term "Community Interpreting" is the most widely used and accepted when describing interpreting for public services. In Canada, interpreters working for public services are also referred to as "Cultural Interpreters" (Mikkelson 1996). However, in the United Kingdom, the term "Public Service Interpreting" was introduced in 1994 when the Diploma in Public service Interpreting (DPSI) was created by the Chartered Institute of Linguists:

The DPSI has developed out of the Community Interpreter project set up in 1983 in conjunction with the Nuffield Foundation. Out of this project came the Bilingual Skills Certificate and the Certificate in Community Interpreting (CCI). In 1994 it was decided to revise the syllabus of the CCI to reflect more closely the changing needs of people using or working with 2 or more languages in the public services. The name of the examination was changed to reflect its status as a professional qualification. The DPSI has been accredited by the Qualification and curriculum authority (QCA) and included in the National Qualifications Framework at level 6. (Hammond 2007: 1) ${ }^{2}$

Recent recommendations from the final report published by the Reflection Forum on Multilingualism and Interpreter Training from Directorate General Interpretation at the European Commission (2009: 10) also commented on the terminology:

'Legal Interpreter/Interpreting' because it is more inclusive than e.g. 'court interpreter' referring to one specific setting only, or 'sworn interpreter' referring to one specific stage in the profession of the legal interpreter while on the other hand, it is not as broad as e.g.' public service interpreter' which also covers other domains such as health and social services. (Reflection Forum on Multilingualism and Interpreter Training 2009: 10) 
The Special Interest Group on Translation and Interpreting for Public Services (SIGTIPS) was set up in 2010 by the European Language Council (Conseil Européen pour les Langues) with the task to produce a report ${ }^{3}$ analysing the situation of translation and interpreting for public services in Europe, identifying problems to be tackled and putting forward recommendations to stakeholders as to how to address what is, without any doubt, a burning issue in Europe. The SIGTIPS group also agreed that the term "public service interpreting" would be adopted as it encompassed earlier works and related to the current reality. However, the translation element was also included as it was acknowledged that public service interpreters also have to translate during some PSI assignments, for example when taking a statement at the police station, hence the new acronym PSIT, Public Service Interpreting and Translation.

As can be seen already, there is a great deal of terminological confusion between the various terms used when discussing interpreting for public services as a profession. In the UK, "Community Interpreting" and "Public Service Interpreting" are both used. The term "Legal Interpreter" could be introduced soon to implement the measures contained in the report mentioned above. This will be an interesting development with a key concern; will it unite and strengthen the profession or will it set up privileged branches of it, leaving behind weakened interpreting sectors such as interpreting for the health sector or local government sectors?

In the UK - though never fully acknowledged - "Community Interpreting" can be understood and perceived as a "less prestigious level" of interpreting services, even with different expectations from service providers (e.g., very blurry line between advocacy and interpreting - lower expectation in linguistic expertise, also reflected in the hourly rate for interpreting services).

Gentile (1997) and Roberts (1997) argue against a classification advocating the single term "interpreting" to avoid divisiveness (Hale 2007). This point of view is reinforced by Mikkelson (1996), who comments that different sectors of the interpreting profession have tried to distance themselves from others deemed to be less prestigious - for example conference interpreters and court interpreters from ad-hoc interpreters - resulting in a weakening of the profession (Hale 2007). Corsellis (2008: 53) takes the debate even further when she comments that the main cause for this difference in training opportunities lies in the lack of commitment on the part of the authorities to insist on the level of competence needed in the public service context and to provide therefore the necessary resources and structures to reach it.

For the purpose of this paper, the term "Public Service Interpreting and Translation" (PSIT) will be used. However, references will include the terms "Community Interpreting" or "Community Interpreters" to describe "Public Service Interpreting and Translating" or "Public Service Interpreters and Translators." The term "Legal Interpreter/Interpreting" will also be included in response to the final report from the Forum on Multilingualism and Interpreter Training from DG interpretation at the European Commission (2009). ${ }^{4}$ 


\subsection{Training courses available for public service interpreters in the UK: issues and challenges}

In the UK, most PSI courses relate to the preparation of three main qualifications:

- Diploma in Public Service interpreting (DPSI), ${ }^{5}$ with three possible options: English/ Scottish Law, Health, Local Government. This is a qualification delivered by the Chartered Institute of Linguists;

- The Bilingual Skills Certificate, also delivered by the Chartered Institute of Linguists. This is a qualification aiming at bilingual workers in the public sector. However, this qualification is often used as a stepping stone towards the DPSI;

- Community Interpreting Certificate: a qualification at level 2 and 3 delivered by the Open College Network London Region.

In addition, PSIT has also been integrated in some post graduate interpreting courses taking the form of one or two modules. However, the MAPSI (Health and Legal) at London Metropolitan University is the only running PSI dedicated course in England. An additional MAPSI is also on offer at Surrey University.

Though undergraduate public service interpreting courses differ, they have a few features in common; training on these courses is mainly a skilled-based approach; courses are assessment-led with mainly a summative assessment approach. There is little awareness of pedagogical principles when teaching PSIT and no formal specialised PSIT quality control. In Further Education, some PSIT classes will be observed by non PSIT specialists for quality control purposes; as a result, the pedagogical feedback is incomplete and does not help PSIT tutors who often are hardworking and willing public service interpreters or language tutors. This is why dedicated PSIT training for trainers is essential with a progression towards accreditation of PSIT courses.

As a result of the lack of organisation and quality control for PSIT training and PSIT assignments, PSIT qualifications are perceived as confusing by stakeholders who will try to book PSIT interpreters at the lowest possible rate. This discourages PSIT interpreters to train further, which in turn hinders the professionalisation of PSIT. This vicious circle has been observed in many countries.

\subsection{Challenges for potential students: lack of accessible and relevant information}

When a person is interested in training as a potential public service interpreter, the first protocol is often to consult the list of 30 PSIT courses.

There, potential interpreters are almost immediately faced with their first challenge: accessing relevant information to understand what is needed to train as a public service interpreter.

As the course leader for interpreting courses at London Metropolitan University, I answer a large number of phone calls with the same questions and concerns over and over again:

- I speak Language $\mathrm{X}$ and $\mathrm{Y}$, I want to be an interpreter, what must I do?

- I bet you don't do my language...

- What course is best suited for me?

- I need to earn a living, I cannot go to school during the day... 
- You mean, I have to pay? How much does it cost?

- I am on income support, where can I get the funding?

- Can I take the qualification without attending the course?

- Is there much work for me?

- Do you think I have the right level?

- My friend is an interpreter, I speak better than him, I want to become an interpreter too.

At the end of the telephone conversation, potential interpreters usually are very thankful and offer voluntary comments about their past frustration regarding:

- the lack of clear information available and

- the lack of a human interface with the profession.

These questions show that there is a need initially for friendly, accessible and professional expertise to guide potential public service interpreters, and for an accurate assessment of their language level, cultural awareness and educational skills.

Though professional interpreting websites provide valuable information, it is not always well understood. When referring to courses, websites do not often provide course objectives with learning outcomes; if they do, they are not always written in a style that is accessible to a non-specialist person.

\subsection{Selecting the right course: a misleading choice}

Potential interpreters usually select their course in different stages. They make their first search geographically; then they look for a course that offers their language combination and finally, they also consider prices. This usually is when they are confronted by their first disappointment, and immediately after they face problems relating to the running of the courses:

- Courses are not available in the language combination requested;

- Students have dropped out and the course has had to close;

- As a result of poor funding, there is not enough money to pay all language specific lecturers;

- There is a lack of resources in interpreting, language and learning support;

- There is little teaching and interpreting expertise available;

- Cross fertilization with expertise from conference interpreting scarcely exists;

- None or little theory is taught;

- There is little understanding of PSIT as a profession and rarely an awareness of the professionalisation process;

- The passing rate for the DPSI is low.

This is also acknowledged by Hale (2007: 6-63), who classifies the main issues around training into four main areas:

- Lack of recognition for the need for training;

- Absence of a compulsory pre-service training requirement for practising interpreters;

- Shortage of adequate training programmes; and

- Quality and effectiveness of the training.

In the UK, PSIT training is available mainly in London and Greater London but it can be quite challenging to easily find a course in other regions. On line courses or correspondence courses are not well established and the use of new technologies 
for virtual training is still in its infancy. In addition, courses in London and Greater London have also had to close down as a result of insufficient funding, expertise or poor interpreting course management skills.

In this context, the geographical selection criteria do not genuinely apply as the selection of running courses is in fact very limited, especially when a specific language combination is required.

Finally, the cost of interpreting courses is often quite high, usually justified by the number of hours that need to be paid to language specific lecturers (in the case of multilingual courses) with no or very few opportunities of sponsoring or funding.

\subsection{Challenges for universities and training centres}

Training centres and universities in the UK and increasingly in many other countries currently operate under immense financial pressure, losing public funding fast. Courses need to be seen as financially viable by senior management. Within this context, PSIT courses with a language specific input find it difficult to survive. The languages needed on the market do not often match languages offered by teaching staff. It is not rare to select 15 students for a course with 12 different languages. How can training and education institutions justify paying a language specific PSI trainer dedicated to only one student, who in addition does not even have a partner to practice interpreting with? Additional resources such as separate rooms for tutorials, recording devices, library resources, and language specific assessors are needed but the costs cannot be met by student fees alone. If training centres and universities still want to remain the focal point and solution for market needs and employability, they need to operate differently.

\subsection{Managing the supply and demand of PSIT services: an issue involving training}

Following consultation with potential employers and interpreting coordinators in public service organisations, it is clearly seen that they have many frustrations, which often stem from a mismatch between supply and demand. The market is overloaded with interpreters in Language $\mathrm{X}$, but what is needed right now is Language $\mathrm{Y}$. The need for Language $\mathrm{Y}$ will often reflect a change in international politics, a new conflict in the world and a large flow of immigrants coming to the UK. This was very much the case with Polish interpreters who were in high demand a few years ago, but not trained to the necessary level. As training takes time, by the time interpreters are able to provide interpreting services at a professional level, the need on the market has shrunk back. It is important to note that according to the Regional Language Network London ${ }^{6} 2008$, over 300 languages are spoken in London (Baker and Eversley 2000). In the last decade, according to "The Impact of recent immigration on the London economy"7 (London School of Economics, 2007), London has seen a net gain of 800,000 immigrants from an increasingly diverse range of countries. More recently (presentation during the launch of EULITA ${ }^{8} 26^{\text {th }}$ November 2009 in Antwerp) Amanda Clement and Michael Brooker from the Language and Cultural Services of London Metropolitan Police estimated that 340 languages were spoken in London. 
Lack of consultation and networking opportunities between PSIT stakeholders such as employers, interpreters, potential interpreters, professional interpreting organisations and training institutions is made worse by a sense of frustration experienced by all parties. This is why as a result of an initial consultation exercise for the curriculum design of the MAPSI (Health and Legal), the Public Service Interpreting Network Group was created in 2009 to bring together PSIT stakeholders to analyse, exchange and agree on strategies that could demonstrate a reflected way forward in the professionalisation of PSIT.

Universities and training centres need and have to learn to work differently, sharing resources and operating on a flexible basis, sometimes sharing students and courses. PSIT stakeholders need to persevere in their desire to professionalise PSIT; resources need to be shared creatively; PSIT needs to aim at excellence and outstanding innovative achievements for the benefit of the profession and PSIT users.

\section{Moving towards a PSIT (virtual) community of practice}

\subsection{Communities of practice within a situated learning model}

It is often assumed that learning has "a beginning and an end; that it is best separated from the rest of our activities; and that it is the result of teaching" (Wenger 1998: 209). But how would things look if we took a different track? Supposing learning is social and comes largely from our experience of participating in daily life? (Smith 2003/2009). Jean Lave and Etienne Wenger rethink the learning process with their situated learning model, involving a process of engagement in a "community of practice."

Communities of practice are formed by people who engage in a process of collective learning in a shared domain of human endeavour: a tribe learning to survive, a band of artists seeking new forms of expression, a group of engineers working on similar problems, a clique of pupils defining their identity in the school, a network of surgeons exploring novel techniques, a gathering of first-time managers helping each other cope. In a nutshell: Communities of Practice are groups of people who share a concern or a passion for something they do and learn how to do it better as they interact regularly. (Wenger circa 2007, ${ }^{9}$ cited in Smith 2003/2009).

This acknowledgement of learning within groups of interest, some formal while others informal, brings forward the debate of pedagogy especially in vocational studies such as PSIT. Cultural and language specific groups, learning groups, studying groups, language specific lecturers have developed their own communities of practice often without realising, with little awareness of the influence they have on their learning. Communities of practice play a vital role in terms of synergies within a cohort of students.

As mentioned in the previous chapter, PSIT requires a language-specific approach during training, generating substantial financial and organizational issues for PSIT stakeholders. However, the concept of communities of practice demonstrates that language specific groups are not the only identified forms of community of practice. Communities of practice affect the learners and the cohort as a whole. This is why the understanding of communities of practice allows the curriculum designer to think beyond language combination groups and look further into other influential factors. "Members are brought together by joining in common activities and by "what they have learned through their mutual engagement in these activities" (Wenger $1998,{ }^{10}$ cited in Smith 2003/2009). 
Participation in a community of practice involves a student-centred approach, where students feel confident to evolve within the curriculum that has been designed to help them understand where they stand within the vocational setting of PSIT, how they can evolve and expand their Zone of Proximal Development (Vygotsky 1978: $86)^{11}$ thanks to the role of the tutor who facilitates learning and generates an environment conducive to learning.

The concept of communities of practice allows thinking beyond the restrictive boundaries of 'courses' and 'courses providers.' One could imagine a large community of practice made of PSIT professionals within which one would find various communities of practice, some more spontaneous and intuitive than others. The first communities of practice that come to mind would be language-specific communities of practice for PSIT, or again trainers of PSIT. When conceptualizing communities of practice, flexibility instead of rigidity comes to mind, partnership and cooperation feel natural instead of competition and isolation. With an agreement on common values for PSIT curriculum design and teaching methodologies that could lead to the accreditation of courses and course providers, communities of practice seem to naturally answer the questions raised by PSIT. A PSIT student could register on a course but benefit from tuition in more than one centre. If language $\mathrm{X}$ is offered in centre A in the North of the country but not in centre B in the East of the country, students with language $\mathrm{X}$ should be able to register to the centre closer to them (either A or B) but benefit from language specific resources in centre A. Sharing resources in such a way would finally contribute to a common effort towards the professionalization of PSIT and PSIT education.

This is a model that could also apply to many other fields. Financial constraints bring terrible challenges but also opportunities to creatively rethink the way institutions operate, forcing stakeholders to address issues that were continuously postponed.

\subsection{Communities of practice within a virtual learning environment}

New technologies and learning environments are developing fast, influencing the way we perceive learning and access information. As far as PSIT is concerned, a Virtual Learning Environment (VLE) would enhance learning, facilitating languagespecific communities of practice. Most teaching institutions already use their own VLE such as Blackboard, Moodle or Weblearn, allowing students to connect to teaching materials on line, uploading and sharing resources, contributing to an enriching dialogue with forums and chats. However, an open VLE across institutions aiming at a wider PSIT community of practice would encourage cooperation and partnerships for the benefit of the PSIT profession. PSIT students would be able to benefit from pooled language-specific and generic resources (human resources such a language-specific PSIT trainers (possibly accredited), audio and video documents, pedagogical tools, training materials such as role plays). Training centres and institutions would then build on their common strengths addressing the needs of the market as they arise, as well as the development of Continuous Professional Development opportunities for PSIT interpreters, hence raising standards and the PSIT profession. PSIT training would then qualify to become PSIT education, educating reflective PSIT stakeholders including service providers, agencies, and practitioners. 
Video conference facilities are continuously improving. Remote teaching and learning is still in its infancy. However, with reliable video conference facilities, communities of practice will include virtual members who could operate on a virtual level. Some universities have already tried to teach with a virtual environment such as Second Life (SL). Operating in a complete virtual environment for PSIT is possible and would deserve further research. In such an environment, technical support is reduced to a minimum.

The open VLE and video conference facilities would allow a student to join and interact in live classes practicing interpreting, interacting with other students in different sites or in class, benefiting from language-specific assessment and guidance. On the other hand, the same person could decide to connect to a class that has already taken place, at a time that suits him or her for a range of reasons, such as professional or family commitments. Finally, the same person may decide to attend classes on-site at convenient times. Such innovative open VLE and video conference facilities will allow students to access PSIT education rather than training, making the most of PSIT resources, in the required language-specific field. A student with a rare language will no longer be the odd one out during pedagogical activities; he will be able to access PSIT education and be trained at the required level ensuring the quality standards set by the profession.

A form of interpreting virtual classes using video conference technology has already been implemented for conference interpreting, mainly within the EMCI network and interpreting services of the European institutions. This project brings together 4 sites, including the interpreting services of the EU institutions which represent employers. A speech might be delivered in Paris, interpreted in Lisbon with feedback given in Brussels. This is an excellent example of partnerships between trainers and employers.

\subsection{Enhancing students' performance and independent learning with a repository system constructed by the PSIT community of practice}

It is easier to practice conference interpreting than PSIT in a remote setting. In PSIT, there are no speeches; simulated events take the form of role plays with consecutive interpreting and chuchotage (whispered simultaneous interpreting), sight translations and written translations. The role plays need to be written in English (for the UK) and adapted to all languages and cultures. They will try to simulate an interview between a police officer and a victim, for example; indeed, it could also be a discussion between a housing officer and a homeless person; however, it might also simulate an emergency conversation over the phone between ambulance services and a pregnant woman who has just fallen down the stairs at home. The legal procedures change from one country to another and role plays need to be adapted. Speeches do not; they mainly need to be updated with current affairs. With PSIT, the dialogue form of the role play implies that non verbal communication skills are vital. For example, in a domestic violence situation, non verbal communication such as posture, eye contact or the lack of it provides additional information to the interpreter who might decide on various shades of meaning depending on the non verbal communication signals sent by this person. This is why sharing resources across training centres and universities as a community of practice is vital. One could imagine an interactive resource 
repository system, such as the speech repository system organised by DG interpretation of the European Commission (SCIC), where role plays would be adapted to different languages and cultures. Students could select their languages and context on the dedicated software; on their screen, there would find two windows, one representing the service provider and the other the speaker of the Other Language (OL). The trainee interpreter would then interpret as they normally would in class, with consecutive interpreting and chuchotage. The interpreting performance would be recorded and stored to be consulted later by the assessor or even sent to a platform to be listened to by others, thus generating group assessment or peer assessment. This already exists for conference interpreting and could easily be adapted for PSIT.

Ko (2006) describes attempts at distance learning, in Canada, the United States, South Africa and China, which took place between 2000 and 2005, and achieved poor results. However technology evolves very fast. Distance Education as defined by Juler (1998, cited in Ko 2006) is already obsolete. Virtual learning with virtual communities of learners and teachers in the spirit of the communities of practice (Wenger 1998 - see note 10) heralds a new era that seems new and innovative as we stand. However, with the development of new technologies, it will quickly become the norm.

The cost of remote teaching and learning is initially very high but it can become cost-effective in the long term (Ko 2006). Once again the market demands will lead the way with new requests to access interpreting services "instantly." In the PSIT industry the development of telephone interpreting services has grown from an expensive industry to a cost-effective operation (toll-free number, internet use, mobile telephony) (Kelly 2008). Software such as Skype, Twitter and MSN bring video telephony to any person that can access a computer with internet facilities. PSIT is already developing as an "instant access service" using video conference calls, mainly in the legal sector in the UK but also very much in use in hospitals in the USA.

\section{Conclusion}

Though this paper focused on the PSIT situation in the UK, it is exciting that a number of projects are now bringing PSIT on the European agenda. It is also encouraging to see that events at international level bring together the PSIT profession embracing Australia and the USA where PSIT has already tried out so many approaches. Many lessons can be learnt from working together at an international level. This is what the Critical Link 6 conference ${ }^{12}$ in Birmingham (2010) demonstrated, bringing together a range of experts from Japan to Australia, reporting on forms of PSIT in Africa, remote interpreting development in the United States with workshops and roundtables.

Moving from PSIT training to PSIT education will take time. This is a marathon for which one needs to pace oneself. In Canada, accreditation of courses is a valuable experience. However, many government decisions have to be made on the value of social justice for all, regardless of origin, culture or language. The new Directive 2010/64/EU ${ }^{13}$ of the European Parliament and of the Council of 20 October on the right to interpretation and translation in criminal proceedings offers hope to PSIT development at national levels. The PSIT current situation in the UK is affected by the current government decisions on financial cuts in the public sector; this is impeding the development of the National Register for Public Service Interpreters (NRPSI) ${ }^{14}$ 
and the National Agreement on Arrangements for the Use of Interpreters, Translators and Language Service Professionals in Investigations and proceedings within the Criminal Justice System, as revised in 2007. ${ }^{15}$

Each of us needs to work towards the development of PSIT, at our own level. Communities of practice offer an excellent framework to evolve in the flexible and intuitive way the profession needs at the moment. New development in virtual setting should not be frightening. On the contrary, Wenger (2002) offers a fantastic range of advice and virtual tools for the development of communities of practice. Organisations such as the PSIT Network Group in the UK demonstrate that the communities of practice framework can help stakeholders from different horizons to meet, share and then move further with projects. The development of a PSIT materials repository for interpreters as described in this paper can only be achieved and used within the mindset of the communities of practice.

\section{NOTES}

1. European Master's in Conference Interpreting. Visited on 10 June 2011, <http://www.emcinterpreting.org/aboutemci.php>.

2. Hammond John, Chief Executive. The Chartered Institute of Linguists. Preface of DPSI Handbook 2007. IOL Educational Trust.

3. SPECIAL INTEREST GROUP ON TRANSLATION AND INTERPRETING FOR PUBLIC SERVICES (SIGTIPS) (2011): Final Report. <http://www.celelc.org/>.

4. DG INTERPRETATION (2009): Reflection Forum on Multilingualism and Interpreter Training. Final report. Brussels: European Commission.

5. Chartered Insitute of Linguists, Diploma in Public Service Interpreting (DPSI). Visited on 16 June 2011, <http://www.iol.org.uk/qualifications/exams_dpsi.asp >.

6. LuDDY, Dominic (2008): The world in one city - The language skills of London's residents - and why we need to make the most of their talent. London Development Agency: Regional Language Network London. Visited on 21 June 2011, <http://www.rln-lon don.com/pdf/world_one_city_report.pdf>.

7. LONDON SCHOOL OF ECONOMICS AND POLITICAL SCIENCE (2007): The Impact of Recent Immigration on the London Economy. London: City of London. Visited on 24 June 2011, <http:// www2.lse.ac.uk/geographyAndEnvironment/research/London/pdf/theImpactofRecentImmigrationOnTheLondonEconomy.pdf>.

8. Clement, Amanda and Brooker, Michael (22 October 2008): The changing face of language service provision for the Metropolitan Police Service - 2012 and beyond. Eulita. Visited on 9 June 2011, $<$ http://eulita.eu/changing-face-language-service-provision-metropolitan-police-service2012-and-beyond>.

9. See also Wenger, Etienne (June 2006): Communities of practice - a brief introduction. Visited on 7 June 2011, <http://www.ewenger.com/theory/>.

10. Wenger, Etienne (1998): Communities of Practice - Learning as a Social System. Systems Thinker. Visited on 7 June 7 2011, <http://www.co-i-l.com/coil/knowledge-garden/cop/lss.shtml>.

11. The Vygotsky project. Visited on 16 June 2011, <http://webpages.charter.net/schmolzel/vygotsky>.

12. Interpreting in a Changing Landscape, $6^{\text {th }}$ International Conference (Critical Link), $26-30$ July, 2010. Aston University, Birmingham, United Kingdon. Visited on 16 June 2011, <http://wwwl. aston.ac.uk/lss/news-events/conferences-seminars/2010-archive/july-2010/critical-link/>.

13. Directive 2010/64/EU of the European Parliament and of the Council of 20 October 2010 on the right to interpretation and translation in criminal proceedings. (26 October 2012): Official Journal of the European Union. L280:1-7. Visited on 12 June 2011, <http:// http://eur-lex.europa.eu/LexUriServ/ LexUriServ.do?uri=OJ:L:2010:280:0001:0007:en:PDF>.

14. National Register of Public Service Interpreters (2001). Visited on 25 June 2011, <http://www.nrpsi. co.uk/>.

15. National Agreement on Arrangements for the Use of Interpreters, Translators and Language Service Professionals in Investigations and Proceedings within the Criminal Justice System, as revised 2007. Visited on 24 June 2011, <http://www.justice.gov.uk/downloads/courts/interpreters/ National_Agreement_on_Use_of_Interpreters-August_2008.pdf $>$. 


\section{REFERENCES}

BAKer, Philip and Eversley, John, eds (2000): Multilingual Capital: The Languages of London's School Children and their Relevance to Economic, Social and Educational Policies. London: Battlebridge Publications.

Corsellis, Ann (2008): Public Service Interpreting: The First Steps. Basingstoke: Palgrave Macmillan.

Gentile, Adolfo (1997): Community Interpreting or Not? Practices, Standards and Accreditation. In: Silvana E. CARr, Roda P. Roberts, Aideen Dufour, et al., eds. The Critical Link: Interpreters in the Community. Amsterdam/Philadelphia: John Benjamins, 109-118.

Hale, Sandra (2007): Community Interpreting. Basingstoke/New York: Palgrave Macmillan.

Kelly, Nataly (2008): Telephone Interpreting. Victoria: Trafford Publishing.

Ko Leong (2007): Teaching Interpreting by Distance Mode. Interpreting. 8(1):67-96.

LAVE, Jean and Wenger, Etienne (1991): Situated Learning: Legitimate Peripheral Participation. Cambridge: Cambridge University Press.

Mikкelson, Holly (1996): The Professionalization of Community Interpreting. In: Muriel M. Jérôme-O'Keefe, ed. Global Visions: Proceedings of the $37^{\text {th }}$ Annual Conference of the American Translators Association. Alexandria: American Translators Association, 77-89.

Roberts, Roda P. (1997): Community interpreting today and tomorrow. In: Silvana E. CARR, Roda P. Roberts, Aideen Dufour, et al., eds. The Critical Link: Interpreters in the Community. Amsterdam/Philadelphia: John Benjamins, 7-28.

Sмiтн, Mark K. (2003/2009): Communities of practice. The encyclopedia of informal education (INFED). Visited on 19 June 2011, <http://www.infed.org/biblio/communities_of_practice. htm>.

Vygotsky Lev S. (1978): Mind in Society: Development of Higher Psychological Processes. Cambridge: Harvard University Press.

Wenger, Etienne (1998): Communities of Practice - Learning, Meaning, and Identity. Cambridge: Cambridge University Press.

Wenger, Etienne, McDermott, Richard and Snyder, William (2002): Cultivating Communities of Practice: A Guide to Managing Knowledge. Cambridge: Harvard Business School Press. 